\title{
The Encouragement of Reading
}

\author{
By ELIZABETH O. STONE
}

\section{The Problem}

$\mathrm{O}$ NE OF THE IMPORTANT AIMS Of a college education should be to make lifetime readers of our students. With the exception of the daily newspaper and a magazine or two, many college students stop reading after graduation. If college students have not been stimulated to read to satisfy intellectual curiosity, or if they have no intellectual curiosity, but have read only that which was assigned, it is quite unlikely that much reading will be done during the remainder of their lives. If this be true they will soon cease to be educated people, as a large percentage of the information gained in college is soon forgotten. It is most likely that a person who was well educated in 1951 is not well educated in 1961 if he has done little reading during the decade. It is doubtful if one can be an effective, intelligent person able to perform his functions as a citizen if he does not keep abreast of the turn of events.

Following are some suggestions of how the reading of college students can be fostered. Many of these ideas have been supplied by librarians in various parts of the country.

\section{The Solution}

\section{I. "Read and Share"}

At one time at Mills College a weekly reading hour was held in the browsing room of the library. Each time the librarian or another member of the faculty read aloud from a book about which she was enthusiastic and which she longed to share with others. The book was described briefly and only enough of it read to whet the appetite. With little effort
Miss Stone is Assistant Director of Libraries for Public Services, Southern Illinois University, Carbondale.

much interest in books can be aroused in weekly sessions such as these.

Illinois State Normal University Library tried the plan of sponsoring book talks by faculty members on interests aside from their subject fields. For example, a sociologist talked on folk poetry. At some institutions such book talks were well attended and resulted in a lively interest in reading.

Book talks have been broadcast with very good results.

Some libraries, such as those of the University of Cincinnati and Kenyon College, sponsor poetry readings by the poets themselves. A famous poet may be brought to the campus each year for a lecture. Other libraries have special poetry rooms, special recorded poetry listening rooms, and poetry librarians to give teas, exhibits, concerts, etc. Poetry readings or lectures are usually well attended.

At the University of Oregon and Colorado State College book talks were given in residence halls during a weekly coffee hour. Sometimes there were student group meetings for reading and discussion of voluntary reading. All such readings, talks, discussions, and reviews usually resulted in a general increase of interest in the subject discussed and an added awareness of the library on the part of students.

It is most important that a sufficient number of copies of a book be available. If interest has been awakened in a subject or in a specific book, interest dies quickly if the book can not be obtained. 
Other important points are to choose discussants carefully and also any student group or groups who may sponsor these programs. Success or failure may depend greatly on these two points.

\section{The Collecting of a Student's Library}

One of the surest methods of stimulating reading is personal ownership of books. Too often students do not realize the great and lasting pleasure that comes from the possession of a well-chosen library; they have not experienced the excitement in books which stimulates personal ownership. Book contests in colleges stimulate the formation of such collections, and students who own books are much more likely to continue to be readers after college days.

Book contests for the purpose of encouraging ownership of books are handled in various ways, and rules for the contests differ. Sometimes an essay describing the purpose of the collection and the reason for the inclusion of the books selected must accompany the entries. The contestant may be required to state how and under what circumstances the collection was made. Sometimes quality of paper and printing are not factors, but others may demand evidence of regard for such characteristics of the book as paper, printing, and edition. Others state that monetary value and number of books is no consideration. Some collections are judged not by size, but by the exactness with which the books fit the interests of the owner and by the content of the collection. Some require that the books shall have been purchased during the academic year and reflect general scholastic enthusiasm and interest. Others require that the collection show that a definite objective has been consistently pursued in the acquisition of the books. Some colleges require an interview with the student, and the judges base awards, in part, upon a student's knowledge of the content of his collection.

Money for prizes may be obtained in various ways. Some usual sources are local book dealers, wealthy donors, budget of library, or from fines and book auctions, student senate, endowment fund, gift books solicited from friends, and "Friends of the Library." Prizes of books to be selected from the local bookstore by the winner are often given.

\section{Browsing Room}

In the browsing area it is important that informal, attractive surroundings and furniture be provided, that smoking be permitted, that new books be constantly added and that the majority of books be withdrawn when they are more than five years old. Place a notebook in the room in which students may write comments about books which they have read from the collection. It is important also to ask for suggestions for additions to the collection. For this purpose mimeographed forms should be provided in the room on which students are invited to list their recommendations.

Book jackets add greatly to the appearance and to the appeal of books in the browsing collection. Plastic jackets may be placed over the publishers' book jackets in order to keep them from becoming torn. They thus present a more colorful and attractive appearance. Although loss by theft is greater with the jackets, librarians agree that it is important that they be retained.

With a browsing collection, books circulate much faster than if they were not on special display. Such a collection results also in on-the-spot reading and builds up worthwhile interest for "aftercollege" reading.

\section{Rental Collections}

At times rental collections have been maintained in the libraries of Oberlin College, Washington University in St. Louis, Iowa State University in Ames, and the University of Pennsylvania to provide current fiction, detective stories, light essays, current books on humor, 
gardening, and house-plans. Material purchased is of current but not necessarily permanent interest and would not be purchased out of departmental funds. The quick availability of books in such collections is much appreciated; the books are popular and enjoyed generally.

There is usually a charge of three cents per day; however, there is a minimum charge of ten cents per book even though the book is returned in one or two days.

\section{Residence Hall Libraries}

Because residence hall libraries are so accessible they may be a vital force in encouraging reading. The collections should be well-maintained, up-to-date, and of good quality. Collections may be rotated each semester among the various residence halls on a campus.

It is quite possible to maintain excellent residence hall libraries with paperback books. For many years paperbacks have been used with great success in the residence halls of Southern Illinois University and for some years at Stanford University. Quality paperbacks are purchased in the fields of fiction, poetry, drama, biography, religion, careers, marriage and sex education, philosophy, psychology, art, and homemaking. These paperbacks need not be cataloged. The ownership mark should be stamped on them, a book pocket pasted in the back of the book, a book card added, and the book is ready to circulate.

\section{Exhibits and Displays of Books}

At Oberlin College, Mills College, and Kenyon College exhibit cases have been turned over to student groups and organizations, the only requirement being that the exhibits must be related to books and reading. Students usually read the books which they have chosen for such exhibits. Some librarians believe that exhibits planned and arranged by students are the best of all ways available to bring students into contact with books.
Almost all libraries make use of bulletin boards or exhibit cases for displays. Display troughs or racks for books are placed on top of the circulation desk so that students will examine them while waiting for books to be charged.

At Vassar College open shelves for specially selected books are found in the circulation lobby or in the main halls where everyone passes. Many libraries maintain a popular literary collection placed near the first floor entrance or near the circulation desk, or there is an informal display of a few selected books on a table in the undergraduate reading room.

Prepare provocative exhibits aimed at the undergraduate and displayed in the corridor adjacent to the undergraduate reading room where traffic is heavy, and where students often pause for a smoke or conversation before entering the room to read or study. It is important that exhibits be maintained at the points along which many students and faculty members pass.

Exhibits may be planned to make people aware of issues, of current events, to display rare books, or to promote general cultural knowledge through the exhibit itself.

New books may be placed on a "new book table" for about seven days. Other libraries may have space to exhibit private libraries of faculty members and students. Favorite books of faculty members, possibly only three or four books at a time, are displayed at Sarah Lawrence College. Southwestern College Library, Winfield, Kans., asked its faculty members to submit a list of the ten books which have had the deepest influence on their lives. They asked that these lists include other types of books than the academic specialty of the faculty member. One might proceed alphabetically through the faculty, and display each group of ten books for only one week. Such exhibits may be followed by displays of "student favorites."

"Notable Books of the Year" an- 
nounced at the ALA Midwinter meeting may be displayed, or if the library does not own all of them the list may be posted along with an indication of those which are owned. Students are much interested, and there is no trouble in getting them to read.

One small exhibit case is used at the University of North Carolina Library for a "Book of the Week," in which one significant book is featured. It may be an important recent gift, or some book that is related to some important event or anniversary. Sometimes the book may be one of extreme local interest and importance or perhaps the publication of a faculty member.

University of North Carolina librarians advocate integration of significant new books with older and perhaps significant books in the same field.

A carefully selected group of older books might bear the caption, "Books You Should Have Read." The number should not be so great that it will discourage reading.

Mills College is an example of a library which endeavors to tie in campus, national or city events, or anniversaries in their exhibits to encourage reading. Use may be made of a current play, opera, movie, or some well-advertised visitor to the city or some event in the daily paper. If such exhibits are not removed immediately after the event is over they become stale and much influence for good is lost. Frequently changed bulletin boards that tie in with students' interests at exactly the right time are believed a successful means of encouraging student reading. Many students choose their free reading only from special shelves where books are displayed in bright jackets. Books that might never move on regular shelves usually go out when placed on a special table reserved for books to encourage reading. The librarian of Iowa State University estimates that books from special shelves in the library circulate three times oftener than those not on special shelves. Accessibility is an important factor, and whatever is featured is often borrowed immediately.

\section{Sale of Books to Students}

Because many students do not have a large budget from which to buy books, paperbacks have offered a helpful solution. This is especially true since so many new scholarly series are offered in this format. Libraries situated in an area where bookstores are either nonexistent or deal in rental of textbooks only are logical places to install a stock of books for sale. Some libraries have copies in their browsing room, but the books are to be ordered through the campus bookstore. This plan was used successfully at Southern Illinois University until a bookstore which maintained a good collection was established. Other libraries stock the books and order any titles requested which are not in stock. On the campuses of the Chicago branch of the University of Illinois and Ohio University, Athens, these sales are conducted in the bookstore and in others directly in the library.

One college bookstore reported that paperbacks had been a failure, but there was a good steady sale of Modern Library and Everyman editions.

At the University of Mississippi covers of paperbacks have presented some problems, but in many of the series the covers are in excellent taste and no attempt is made at sensationalism. There is expense involved in selling books or in taking orders for them, but when routines are established such costs can be cut to a minimum.

Book auctions and book fairs have been quite successful in various institutions such as Antioch College. At Saint Mary College Library, Xavier, Kans., books are supplied by a bookstore on commission, and unsold books may be returned. At St. Bonaventure Library, St. Bonaventure, N. Y., a literary society was willing to sponsor such activities and pro- 
vided attendants to supervise the sale of good pocket editions of value to students. Books which have been withdrawn from the library or gifts which were never added are sold for ten cents each by Wells College, Aurora, N. Y. At Antioch College the books are placed on display for one week prior to the sale. This is done to permit bidding by students and faculty members. Money received from book sales or book auctions is used to augment the book fund in some libraries.

\section{The College Newspaper}

Book news and reviews in college newspapers vary from nothing at all or from very sporadic efforts to lengthy reviews which may or may not be written by a library staff member and appear in every issue. Mills College Library reports that sporadic attempts to publish book news are likely to be made when someone with bookish interests joins the newspaper staff.

At Sarah Lawrence College a series of articles by faculty members has been run in the college newspaper on "My Favorite Book." The librarian followed this up with a display of the books mentioned.

At Northern Illinois University every issue of the college newspaper had a boxed-in notice, "Have You Read?" followed by author, title, and annotation.

Another possibility is to feature the "Book of the Week."

In one college newspaper appeared a monthly column, "Reading We've Liked."

The librarian of St. Joseph's College for Women in Brooklyn, N. Y., provided the college newspaper each month with her recommendation of a periodical. For one issue she recommended Camping Magazine as being of especial interest to undergraduates who intended to be camp counselors during the summer.

Lists which may prove useful are:

Weekly suggestions for week-end read- ing that can be reserved in advance Suggestions for holiday reading

Greatest books, compiled by a professor at the institution

Books especially enjoyed by faculty members

Books especially enjoyed by students Books recommended for vacation reading during the summer

New paperbacks

Weekly leaflet containing brief reviews (a few sentences only) calling attention to books of special interest and value (not necessarily news ones).

Reports vary as to the benefits gained. Some librarians stated that books written about in the college paper are usually asked for at once in the library and felt that reviews should be encouraged as a regular feature. One librarian reported that such reviews had little effect in encouraging reading. Criticisms of book news are that the articles are too infrequent, and that they are not snappy or colorful enough.

For those colleges and universities which publish literary magazines, book notes, annotations, and reviews are also included.

IX. Methods Used By Faculty Members To Stimulate Reading of Students

Faculty influence on the reading of students is rated very high, by all librarians. Duke University Library states that "classroom stimulation is all important to the growth of student reading. Without it a college or university library operates completely in a vacuum." Oberlin College believes that "only by getting the complete cooperation of the faculty can the library staff hope to increase the library use by students." Sarah Lawrence College Library believes that the most successful method to encourage reading is a professor's recommendation of a book. "This seems to arouse a student's interest as no other method does."

Katharine Stokes has said: "The best efforts of the library must be aimed at 
the faculty if the greatest number of students is to be reached." 1

Although there are many little things the librarian can do in encouraging student reading the important thing is the interest, and enthusiasm and inspirational ability of the faculty. We need to attract a high grade of faculty member and to emphasize the humanities and the basic sciences and de-emphasize vocational studies in the undergraduate curricula. No matter how effective a librarian may be on his job, no matter how many books he acquires and how many services he gives, students must learn to read through direct and immediate contact with their teachers, and, in turn, these teachers must be competent to teach them to read.

If there is nothing like an inspiring teacher who loves books, what are some of the methods used by such a teacher to stimulate reading?

A. The most casual mention in class by a well-liked and admired faculty member tends to set wheels in motion. Enthusiasm about a book by one faculty member can cause a run on that book at the library. Faculty members may do much in suggesting worthwhile books during lectures and class discussions.

B. Informal meetings between faculty members and students are most helpful in stimulating reading. These meetings are not conducted by organized plan, but in casual conversation between classes or over a cup of coffee, or at a tea hour.

C. Students may be given an opportunity to discuss ideas derived from books read and to give special reports.

D. Instructors may interest students by reading excerpts from books which they have read and wish to recommend.

E. A personal copy of a book recommended for reading may be placed on reserve by a faculty member.

F. Reading lists of biography and fiction titles may be compiled in coopera-

1 Katharine M. Stokes, “Selling the College Library's Services," CRL, IV (1943), 120-27. tion with the librarian. These may be used most effectively in sociology and history courses.

G. Monthly acquisition lists may be sent by the librarian to faculty members. These lists may be made available to students at the circulation desk. From these lists, faculty members recommend books to students.

H. Some of us believe that faculty members encourage reading by "so teaching that they arouse intellectual curiosity," or "by teaching wisely."

I. Faculty members may bring or send individuals and groups to the library. Occasionally library talks may be given by faculty members in library stacks to small groups of students by way of a combined bibliographical acquaintanceship and stimulation.

J. Reading is encouraged if students are assigned to debate a "hot" dispute which has come up in class.

K. Faculty members at the University of Oregon encourage the development of personal libraries and help students build for purchase and for recreational reading.

L. Faculty members may sometimes give book reviews in assembly.

M. Recommendations of good books may be made in student-faculty literary clubs and in honorary fraternities, or in departmental clubs.

N. Advisory service on reading may be given through personal interview and discussion. At Sarah Lawrence College each student has a personal interview with her instructor at least once in each two weeks. They discuss what she has read and what she will read. The conference lasts one-half hour and is most effective.

O. According to the librarian of Sarah Lawrence College students like to talk over with their teachers what they have read. Nothing can take the place of this.

While some students like to read and do read widely, it is evident that faculty members can do much to stimulate read- 
ing. The librarian of Baldwin-Wallace College, Berea, Ohio, stated that "the bulk of all reading done in a college is the result of classroom stimuli," while the librarian of Sarah Lawrence College stated it thus: "More than anything, students are not inclined to read any more than they have to, but professional stimulation will help to push non-required titles more than anything else."

The Vassar College librarian stated it in this fashion: ". . . Students must be constantly prodded before they become book conscious."

It behooves every librarian to make as much use as she possibly can of faculty aid in encouraging students to read. There is much which they can do which she can not.

\section{Help from Students in Encouraging Reading}

A student library committee may use various techniques each year to encourage reading, such as taking reading to people in the infirmary, getting students' comments on books they like, preparing a week end shelf, getting students to vote on their favorite books, preparing lists of popular reading books in various fields, and in other ways. A student library committee working toward such a goal is one of the best ways of encouraging reading by students.

Miss Elizabeth J. McCloy, former librarian of Occidental College, says that a recommendation by a fellow student is one of the best ways to get readers. Students may assist in the selection of recreational reading books. They may fill out forms for suggested purchases and leave at the circulation desk, or in a suggestion box on top of the card catalog.

Students may meet with the librarian to select some books to be added each year to the residence hall library.

\section{Special Reading Courses and Reading Clubs}

Duke University Library mentioned that it would like to encourage the development of a reading course in the curriculum along the lines of that at Trinity College, Hartford, Conn. Its students complained repeatedly that they want to read but that class assignments were too heavy with required outside reading to permit much "free reading." Some portion of this complaint appeared to be justified, and it is believed that a number of students would be interested in a pure reading course. There are several informal reading groups on their campus at present. On some campuses there are book clubs for upperclassmen and separate reading clubs for lower classmen.

Harvard University President, Dr. Nathan Pusey, has suggested the desirability of establishing an honors reading course based on lists supplied by deans of the various colleges. It is felt that this is an excellent way to stimulate reading and to form a lifelong habit.

\section{SUMMARY}

Who can say which methods of encouraging reading of college students will prove most effective in a given library? Experimentation with various methods may produce the answer. Book discussions, talks, reviews, play reading, or poetry reading by the poets themselves held in the browsing room or in residence halls may be effective. Contests for book collections owned and selected by students are popular at various institutions. Browsing or rental collections result in increased reading, as do some exhibits and displays of books. Residence hall libraries provide books for students in their living quarters at college. This habit of "living with books" may result in the student buying books for his own home. The importance of book purchases can not be emphasized too greatly since ownership of books stimulates reading. The student with limited resources can own many excellent books selected from the mounting 
paperback publications. Reviews or book notes published in the college newspaper or lists on various subjects such as "Great Books," "New Paperbacks," "Books Especially Enjoyed by Faculty Members," "Books Especially Enjoyed by Students," may stimulate reading. Prizes may be given to students for the best lists of books suggested for purchase. This device has value as the student becomes acquainted with book selection aids. Book reviews or discussions on radio and television may play an important part in interesting people in reading. Faculty influence on the reading of students is rated very high by all librarians. The most casual mention of a book in class by a well-liked and admired faculty member tends to set wheels in motion. Excerpts read from a book in class may cause a run on a book. Any instructor who teaches so that he arouses intellectual curiosity will stimulate reading on the part of his students. Unplanned, informal meetings between faculty members and students are conducive to read- ing when books enter the conversation. Students may help in stimulating the reading of other students by selecting a week end shelf of books to recommend to their fellow students, by preparing a list of popular reading books in various fields, by getting comments on books students like, by getting students to vote on their favorite books, or by getting students to suggest books for purchase for recreational reading. Informal reading groups may be organized on the campus. A pure reading course may be offered since students sometimes justly complain that they are too busy to read anything except class assignments. An honors reading course based on lists supplied by deans of the various colleges may be established.

Whatever methods used, if you succeed in endowing your students with lifetime reading habits so that reading becomes attractive to them you have done much to aid in the progress of education and in the development of an informed citizenry.

\section{Alternatives to a New Library Building}

(Continued from page 35t)

give funds for an addition but would not contribute to a new structure. The sentimental value of an old building may be so great that it would be unwise to discard it or use it for other purposes. The library of Delaware State College in Dover has occupied the oldest building on the campus for many years-a building that was once the chapel of the slave plantation on which the college developed after the Civil War; students and faculty regard it with great affection as the heart of the institution. The college was fortunate in being able, without materially changing the character of this building, to enlarge it and continue to use it for its library.

Despite all difficulties, the possibilities of an addition ought to be examined before it is decided to give up an old building. It will often be desirable to call in an architect, a builder or a library consultant or all three to make sure that an addition is practicable. The costs ought to be estimated as carefully as possible and the advantages and disadvantages assessed. No simple formula will take the place of thoughtful study in light of the library's future and the institution's educational program.

COLLEGE AND RESEARCH LIBRARIES 